\title{
Influence of the fungi population on the physicochemical and chemical composition of coffee (Coffea arabica $\mathrm{L}$.)
}

\author{
Influência da população fúngica na composição físico-química e química do grão de café (Coffea arabica L.)
}

\author{
Liliana Auxiliadora Avelar Pereira PASIN ${ }^{1 \star}$, Mário Sobral de ABREU², Igor Pereira SOUZA ${ }^{3}$
}

\begin{abstract}
The influence of fungi associated with coffee fruits was verified regarding the chemical and physicochemical composition of Coffea arabica L. raw grains. The fruits were harvested at EPAMIG Experimental farm in Lavras, State of Minas Gerais - making up the different samples here analyzed. After processing and drying, the grains were incubated in wet chamber for fungal exteriorization through the blotter test method and submitted to the following analyses: polyphenoloxidase, total reducing and non-reducing sugars, clorogenic acid, titrable acidity, potassium leaching, electric conductivity and caffeine. The occurrence of the P. variable, P. rugulosum, P. funiculosum, F. equiseti, F. semitectum, A.alutaceus, A. niger and C. cladosporioides fungi in the different samples was detected. From the analysis of the results obtained, it was observed that the presence of the Aspergillus alutaceus fungus reduces the activity of the enzyme polyphenoloxidase and increases the values of potassium leaching, electric conductivity and chlorogenic acid. The incidence of the Cladosporium cladosporioides fungus influenced the average values of potassium leaching and electric conductivity.
\end{abstract}

Keywords: fungi incidence; coffee quality; bromatological parameters.

\section{Resumo}

Verificou-se a influência dos fungos associados aos frutos de café na composição físico-química e química do grão beneficiado de Coffea arabica L. Os frutos foram colhidos na fazenda Experimental da EPAMIG, no município de Lavras-MG. Após beneficiamento e secagem, os grãos foram incubados em câmara úmida para exteriorização dos fungos através do método blotter test e submetidos às análises de polifenoloxidase, açúcares totais redutores e não redutores, ácido clorogênico, acidez titulável, lixiviação de potássio, condutividade elétrica e cafeína. Verificou-se a ocorrência dos fungos Penicillium variable, P. rugulosum, P. funiculosum, Fusarium semitectum, F.equiseti, Aspergillus alutaceus, A. niger, Cladosporium cladosporioides. Pela análise dos resultados obtidos observou-se que a presença do fungo Aspergillus alutaceus reduz a atividade da enzima polifenoloxidase e aumenta os valores de lixiviação de potássio, condutividade elétrica e fenólicos totais. A incidência do fungo Cladosporium cladosporioides influenciou nos valores médios de lixiviação de potássio e condutividade elétrica.

Palavras-chave: incidência fúngica; qualidade do café; parâmetros bromatológicos.

\section{Introduction}

Coffee is a major source of revenue for Brazil, with great social and economic effects, and it stands as one of the most popular beverages in the world. About $70 \%$ of Brazilians make daily use of this product (POZZA et al., 2000), resulting in a marked increase in domestic consumption of Brazilian coffee. This growth can be attributed to a number of factors, pointing mainly to continuous improvement. Currently, the quality of agricultural products, especially coffee, has encouraged the development of studies aimed at understanding the factors that directly affect quality. It should also be considered that the coffee is distinguished among the agricultural products that have their prices based on qualitative parameters, whose value increases significantly with improved quality. However, this quality is dependent on several factors related to all stages of coffee production, from the choice of variety to be planted to the brewing (MENDONÇA et al., 2005).
Several factors directly affect the quality of coffee. One of the highlights is the chemical composition of the grain, which is determined by genetic, cultural and environmental factors; the process of preparation and storage of the grain, in which the temperature and humidity play a critical role, since they can provide microbial infections and undesired fermentation. Among these aspects, microbial infection of the coffee beans can harm its appearance, taste and aroma, as well as the product safety.

The fruits (peel, pulp and seed) are used as a substrate for the growth of bacteria, yeasts and filamentous fungi, filling them with carbon and nitrogen present in cellulose, hemicellulose, pectin, reducing sugars, sucrose, starch, oils acids, protein and caffeine. Of all the organisms that comprise the microflora of coffee, filamentous fungi represent the most relevant group, since they are more frequent and can cause losses such as

2 Departamento de Fitossanidade, Setor Fitopatologia, Universidade Federal de Lavras - UFLA, CEP 37200-000, Lavras, MG, Brasil

${ }_{3}^{3}$ Laboratório Fitopatologia, Fazenda Experimental Santa Rita, Empresa de Pesquisa Agropecuária de Minas Gerais, CEP 35701-970, Sete Lagoas, MG, Brasil

${ }^{*}$ Corresponding author 
biochemical transformations in the grains (PIMENTA; VILELA, 2003).

The association of fungi on seeds and grain may occur during all stages of production, including post-harvest, in storage conditions, and it is a major cause of qualitative depreciation. The first reports on the influence of filamentous fungi in coffee quality were produced in the thirties, with the detection of Fusarium mycelium in samples of fermented grain. Since then, several studies showed the presence of filamentous fungi in coffee beans (PIMENTA; VILLELA; MORAES, 2002; CHALFOUN; BATISTA, 2003).

The fungal species most frequent in coffee are included in the Aspergillus, Penicillium, Fusarium genera (BATISTA et al., 2003, BATISTA; CHALFOUN, 2007). All reports showed that the incidence of fungal directly influences coffee drink; however, research on the physical and chemical changes of the grains is still incipient. Thus, the objective of this research was to verifity the influence of different fungi on the fruits of coffee (Coffea arabica L.) regarding the physico-chemical and chemical compositions of the raw grain.

\section{Materials and methods}

A lot of coffee beans Coffea arabica L. obtained to carry out the analyses was harvested from the Acaiá Cerrado MG 1474 cultivar, through hand-stripping on the cloth in the Experiment Station farm in Lavras, State of Minas Gerais. The cultivation system used was free growth. The growth conditions were those recommended for coffee crop in the region. Five samples of $30 \mathrm{~kg}$ were harvested.

Once harvested, the fruits remained in the yard until they reached moisture content of about $12 \%$. Upon reaching the proper moisture content the grains were collected, double packed, and stored at the Laboratory for Disease Control, Plant Pathology Department, Federal University of Lavras, until the time of analysis.

In order to evaluate the incidence of fungi, the grains were distributed in Petri dishes of $15 \mathrm{~cm}$ in diameter, containing three sheets of filtering paper previously moistened in sterile distilled water for further incubation. After drying, 100 grains were taken at random for subsequent distribution in aseptic conditions, 25 grains per plate, as the blotter test technique. Each plate with 25 grains was considered a repetition. The grains were incubated in a $20 \pm 2{ }^{\circ} \mathrm{C}$ chamber with a photoperiod of 12 hours of black light (wavelength near ultraviolet) for eight days until the manifestation and development of the fungi. The identification of the fungi was done by examining each individual grain, using the staining of colonies and spores method at microscopy, after eight days of incubation.

In order to perform the chemical analysis, a sample of $200 \mathrm{~g}$ of green beans was used. The samples were ground in mill (Tecnal brand, T 650 model) and sieved through 20 mesh sieves. Evaluations of total acidity, chlorogenic acid, caffeine, potassium leaching, electrical conductivity, total sugars, reducing and non-reducing, and enzyme activity of polyphenoloxidase. The evaluation of PPO activity and total acidity was performed immediately after milling, no alterations in the material. For the electrical conductivity and potassium leaching analises, separated $100 \mathrm{~g}$ of green beans were separated.

The determination of the amount of potassium leaching was assessed in a flame photometer Digimed NK -2002, after 3.5 hours of beans soaking, according to the methodology proposed by Prete and Abrahão (2000).

The electrical conductivity of the raw grains was determined by adapting the methodology recommended by Kryzynowski, Françaneto and Henning (1991). 50 grains of each sample were used, they were weighed $(0.001 \mathrm{~g}$ precision $)$ and immersed in $75 \mathrm{~mL}$ of deionized water inside $180 \mathrm{~mL}$ plastic cups. Subsequently, these containers were placed in ventilated oven set at $25^{\circ} \mathrm{C}$ for five hours; after that, the reading of the electrical conductivity of the solution was performed in a Digimed CD player -20. From the data obtained, the electrical conductivity was calculated and the results were expressed in $\mu \mathrm{Sm}^{-1} \mathrm{~g}^{-1} /$ sample.

The enzyme extract used for the determination of the PPO activity was obtained by adjusting the extraction process described by Draetta and Lima (1976). $5 \mathrm{~g}$ of green beans were weighed, then, $40 \mathrm{~mL}$ of phosphate buffer potassium $0.1 \mathrm{M} \mathrm{pH} 6.0$ was added and stirred for 5 minutes, and the used items were kept under refrigeration. After shaking, the samples were subjected to vacuum filtration using Whatman paper $\mathrm{n}^{\circ} 1$. The enzymatic activity was determined by the method described by Ponting and Josling (1948), using the sample extract without DOPA as white.

Caffeine was assessed by the colorimetric method described by Instituto Adolfo Lutz (1985).

The total sugars and reducing sugars were extracted by using the Lane-Enyon method, described by AOAC (ASSOCIATION..., 1990). The non-reducing sugars were found by difference between total and reducing sugars. Values were expressed as percentage.

The total acidity titled was determined by titration with $0.1 \mathrm{~N} \mathrm{NaOH}$, adapting the methodology cited by AOAC (ASSOCIATION..., 1990). $2 \mathrm{~g}$ of coffee sample were weighed and added to $50 \mathrm{~mL}$ of distilled water, the mixture was shaken for 1 hour. Then, filtering was performed on filter paper and $5 \mathrm{~mL}$ of the filtered solution was withdrawn and, placed in a flask containing $50 \mathrm{~mL}$ of distilled water. 3 drops of phenolphthalein were added and then titrated with $\mathrm{IN} \mathrm{NaOH} 0.1$ Results were expressed in $\mathrm{mL}$ of $\mathrm{NaOH} 0.1 \mathrm{~N}$ per $100 \mathrm{~g}$ of sample.

The determination of the chlorogenic acid content of the samples was performed according to the methodology proposed by Menezes (1990), weighed to $0.5 \mathrm{~g}$ of previously ground sample was weighed, after that, $100 \mathrm{~mL}$ of $70 \%$ isopropanol was added, and then placed in reflux for 4 hours at $50^{\circ} \mathrm{C}$. Subsequently, the mixture was filtered and the volume completed to $100 \mathrm{~mL}$ with isopropanol $70 \% .1 \mathrm{~mL}$ of the extract mixed with metaperiodate reagent to $0.25 \%$ was withdrawn; this extract remained for 10 minutes at $27^{\circ} \mathrm{C}$. The reference sample consisted of $1.0 \mathrm{~mL}$ of $70 \%$ isopropanol and $10 \mathrm{~mL}$ of reagent metaperiodate to $25 \%$. Subsequently, there was a meter reading on the spectrum to $406 \mathrm{~nm}$. 
The statistical analysis was performed using the program Statistica 6.0 (Statsoft Inc., Tulsa, OK, USA). Analysis of variance and the fungi present in the grains quantitative variables were used. The responses of the chemical components of grain for the presence of fungi were determined by regression equations. Graphs were constructed for the regression equations when there were detected significant effects $(p \leq 0.05)$ of responses in relation to fungal occurrence.

\section{Results and discussion}

The following fungi were found in the grains listed below: Fusarium semitectum (83.0\%), Fusarium equisetum (87.0\%), Penicillium rugulosum (82.0\%), Penicillium funiculosum (79.0\%), Penicillium variable (37.0\%), Aspergillus alutaceus (42.0\%), Aspergillus niger (8.0\%); Cladosporium cladosporioides (91.0\%) and Rhizopus (1.5\%).

The genera Fusarium, Penicillium, Aspergillus and Cladosporium are commonly associated with coffee beans, and several studies relate the occurrence of Fusarium sp. and Aspergillus sp. to coffee drink previously classified wih relationship to the patterns such as riada and rioy. The fungus Cladosporium sp. was reported as prevalent in coffee drinks classified as "soft" and "hard" (CARVALHO et al., 1989; ALVES; CASTRO, 1998). However, the studies do not relate to the grain microflora associated with the physicochemical and chemical properties of grain.

The results obtained in this study, among the fungi detected in the analyzed samples, only the fungus Aspergillus alutaceus was influenced by the values of enzymatic activity of polyphenol oxidase, showing that this fungus, and the produce secondary metabolites, such as OTA, can interfere with the chemical composition of grains, especially with the PPO activity (Table 1).

It was observed that for each increase of $4 \%$ occurrence of Aspergillus alutaceus there is a reduction tendency of 1.1534 in the activity of this enzyme (Figure 1). Carvalho et al. (1994) studied the relationship between the classification of the coffee beverage and the chemical composition with the microflora associated with the benefited grain, and concluded that the determination of the PPO activity allows a more objective evaluation of the coffee quality. Chalfoun (1996) further argued that the activity of this enzyme is a reliable parameter for the quality evaluation of coffee, since we drink coffee which has lower quality of polyphenoloxidase enzyme activity. Pimenta, Villela and Moraes (2002) found that PPO activity was significantly reduced in periods of storage up to 270 days. The authors also observed a significant increase in infection by Aspergillus sp. from 180 days of storage; this result showed that the increase in Aspergillus sp. infection may contribute to the reduction of the enzyme activity and, consequently, to the quality of the drink.

The Cladosporium cladosporioides fungus predominated in coffees classified as soft and hard drink (CARVALHO et al., 1994). However, in the present study, the fungus Cladosporium cladosporioides, although detected in the samples, did not exert any direct influence of the polyphenol oxidase enzyme (Table 1).

Alves and Castro (1998) also reported a relationship between the incidence of the Fusarium, Aspergillus and Penicillium genera and the inferior quality drinks. The species detected in Fusarium and Penicillium genera did not influence the activity of polyphenoloxidase, even at high incidence (Table 1).

It could be observed that that only Aspergillus alutaceus fungus interferes with the content of chlorogenic acid, and that for every $4 \%$ increase in the incidence of this fungus, there was an upward trend of 0,062 in the content of chlorogenic acid (Table 1, Figure 1b).

The coffee bean has a variety of phenolic and most important, depending on the amount found in grain are chlorogenic acids, which have an inverse relationship with coffee quality. Higher content of total chlorogenic acids may be found in low-grade coffee (SILVA et al., 2000). These acids exert a protective action - antioxidant and aldehydes are generally considered secondary products of plants. The presence of these compounds in coffee - in excess, if compared to those recorded for certain species - is associated with the devaluation of the quality, suggesting that these compounds may also serve to assist in assessing coffee quality.

Table 1. F values related to the activity of polyphenoloxidase $\left(\mathrm{U} \cdot \mathrm{min}^{-1} \cdot \mathrm{g}^{-1}\right)$, chlorogenic acid (\%) Potassium Leaching (ppm), electrical conductivity $\left(\mu \cdot S^{-1} \cdot \mathrm{g}^{-1}\right)$ in samples of coffee received raw.

\begin{tabular}{|c|c|c|c|c|}
\hline Sources of variation & Polyfenoloxidase & Chlorogenic acid & $\mathrm{K}^{+}$Leaching & Electrical conductivity \\
\hline F. semitectum & $0.3643^{\mathrm{n} . \mathrm{s}}$ & $1.09^{\mathrm{n} . \mathrm{s}}$ & $0.13^{\mathrm{n} . \mathrm{s}}$ & $1.49^{\mathrm{n} . \mathrm{s}}$ \\
\hline F. equiseti & $0.0959^{\text {n.s. }}$. & $2.86^{\mathrm{n} . \mathrm{s}}$ & $0.02^{\mathrm{n} . \mathrm{s}}$ & $0.52^{\mathrm{n} . \mathrm{s}}$ \\
\hline P. variable & $2.84^{\mathrm{n} . \mathrm{s}}$ & $1.36^{\mathrm{n} . \mathrm{s}}$ & $1.41^{\mathrm{n} . \mathrm{s}}$ & $0.63^{\mathrm{n} . \mathrm{s}}$ \\
\hline P. rugulosum & $2.70^{\text {n.s. }}$. & $0.03^{\mathrm{n} . \mathrm{s}}$ & $1.18^{\mathrm{n} . \mathrm{s}}$ & $0.58^{\mathrm{n} . \mathrm{s}}$ \\
\hline P. funiculosum & $2.34^{\mathrm{n} . \mathrm{s}}$ & $0.61^{\mathrm{n} . \mathrm{s}}$ & $0.00^{\mathrm{n} . s}$ & $0.71^{\mathrm{n} . \mathrm{s}}$ \\
\hline Cladosporium sp. & $0.32^{\mathrm{n} . \mathrm{s}}$ & $0.00^{\mathrm{n} . \mathrm{s}}$ & $7.32^{*}$ & $6.91^{*}$ \\
\hline A. alutaceus & $10.27^{\star}$ & $4.13^{*}$ & $6.82^{*}$ & $5.65^{*}$ \\
\hline A. niger & $2.45^{\text {n.s }}$ & $0.10^{\mathrm{n} . \mathrm{s}}$ & $0.05^{\mathrm{n} . \mathrm{s}}$ & $0.04^{\mathrm{n} . \mathrm{s}}$ \\
\hline Rhizopus sp. & $0.09^{\text {n.s }}$ & $0.10^{\text {n.s }}$ & $0.04^{\text {n.s }}$ & $0.31^{\mathrm{n} . \mathrm{s}}$ \\
\hline Model & $86.92^{\star *}$ & $40.09^{\star *}$ & $13.02^{\star *}$ & $7.34^{* *}$ \\
\hline C.V(\%) & 0.65 & 4.99 & 4.46 & 10.06 \\
\hline
\end{tabular}

${ }^{*} \mathrm{P} \leq 0,01 ;{ }^{*} \mathrm{P} \leq 0,05$. 
Phenolic compounds are related to the enzymatic activity of some enzymes, acting as the main substrate. Any injury that occurs in grains, including those caused by microorganisms, can promote the disorganization of the cell, leading to the interaction between enzyme and substrate and, consequent, to the production of quinones, which react with other proteins and enzymes, promoting its inactivation (ARAÚJO, 1990).

The result of this study did not confirm what was proposed by Amorim et al. (1974), who suggested that when the content of chlorogenic acid is higher in quality coffees in lower coffee quality, lower depending on the attack of the fungus Fusarium sp., indicating that the presence of this fungus induces the production of higher levels of acid. As the content of this compound, and consequently the total phenolic content, is associated with loss of quality, every work that relates the higher percentage of occurrence of fungi in coffee of inferior quality may suggest that every fungus also alter the total phenolic content. However, this association was not confirmed in this study (Table 1), since only a few fungi altered the values of chlorogenic acid.

Alves and Castro (1998) related the occurrence of Fusarium with drinks of lower quality, the occurrence of Fusarium equiset $i$

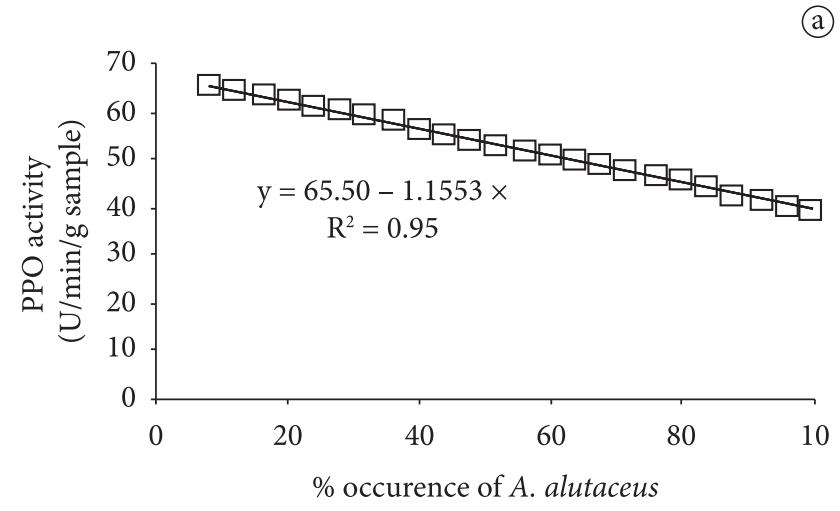

(a)

(c)

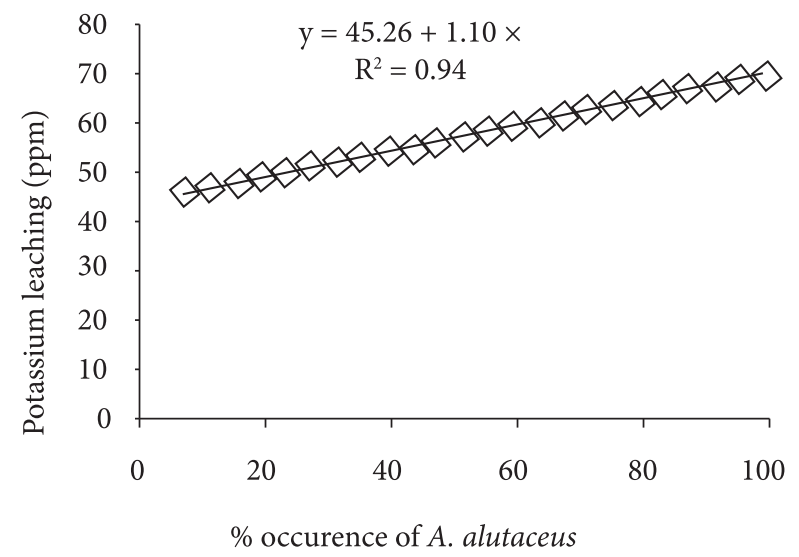

and Fusarium semitectum was detected in some samples analyzed in this study, but these fungi did not influence the content of a substance, even in conditions of high incidence. However, Carvalho et al. (1989) report that the Fusarium sp. and Penicillium sp. Fungi showed, similarly, high rates in different classifications proposed by coffee Garruti and Conagin (1961). These results confirm what was observed in this study.

Several authors have mentioned a relationship between high incidence of Aspergillus alutaceus fungus and coffee samples classified as lower quality drinks (CARVALHO et al., 1989; ALVES; CASTRO, 1998). This study confirms a relationship between this fungus and the content of chlorogenic acid, one of the factors which disparage the quality of the drink.

The highest values of potassium leaching and electrical conductivity were observed in samples which showed higher incidence of Aspergillus alutaceus fungus; analysis of variance indicated an increasing trend of these parameters with the increase of this fungus. However, this was also verified for Cladosporium cladosporioides fungus (Table 1). Among the fungi detected in the samples, only Aspergillus alutaceus and Cladosporium cladosporioides fungi exerted a direct effect on these variables. It was observed that for each increase of
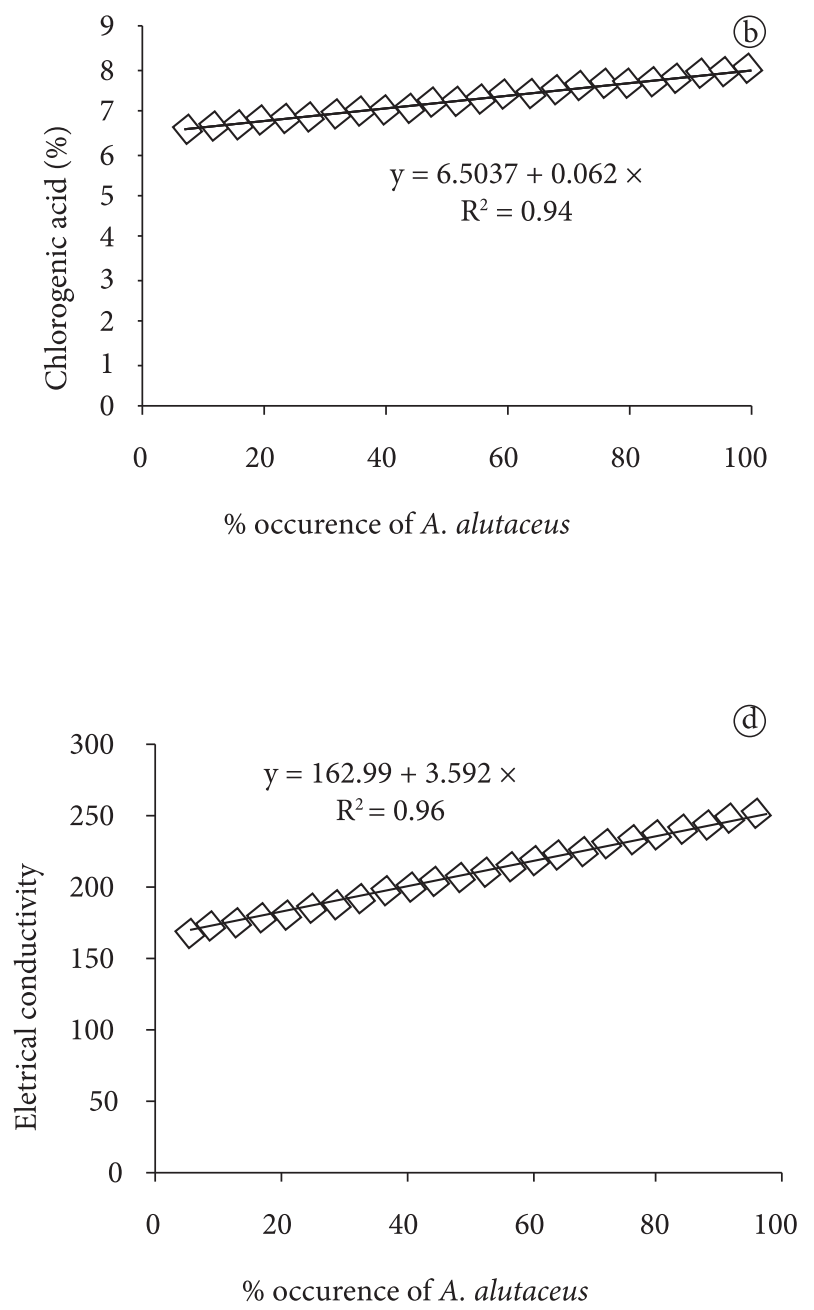

Figure 1. Effect of incidence (mean\% of occurrence) of the A. ochraceus fungus in polyphenoloxidase activity (u/m/g), chlorogenic acid content (\%) potassium leaching $(\mathrm{ppm})$, and electrical conductivity $(\mu / \mathrm{S} / \mathrm{g})$ in processed coffee beans. 
$4 \%$ of Aspergillus alutaceus fungus, there was an increase tendency of 1.10 in the potassium leaching amount and of 3.592 in the electrical conductivity amount (Figure 1c,d). For Cladosporium cladosporioides fungus, every $4 \%$ increase in incidence was connected to an upward trend of 0.558 in the potassium leaching amount and of 0.96 in the electrical conductivity values (Figure 2a,b). Tests of $\mathrm{K}+$ leaching and electrical conductivity have been presented as indicators in assessing the integrity of the membrane. There are higher rates of potassium leaching and electrical conductivity in samples of lower quality coffees. The results showed that coffees that have suffered deterioration of quality had their membranes affected. Once the membrane structure is ruptured, there is greater contact between the enzymes and the intra and extracellular components, what causes changes in the composition, and thus, in the quality of grain (REINATO, 2003; FAVARIN et al., 2004).

The membranes are the first to be affected by adverse conditions in coffee. Commonly, the damage occurs in the pre and post-harvest periods due to insect and microbial infections; some authors concluded that the fungus of the genus Cladosporium predominated in coffees classified as top quality drinks (CARVALHO et al., 1989; ALVES; CASTRO, 1998), but the results obtained in this study did not confirm this relationship.

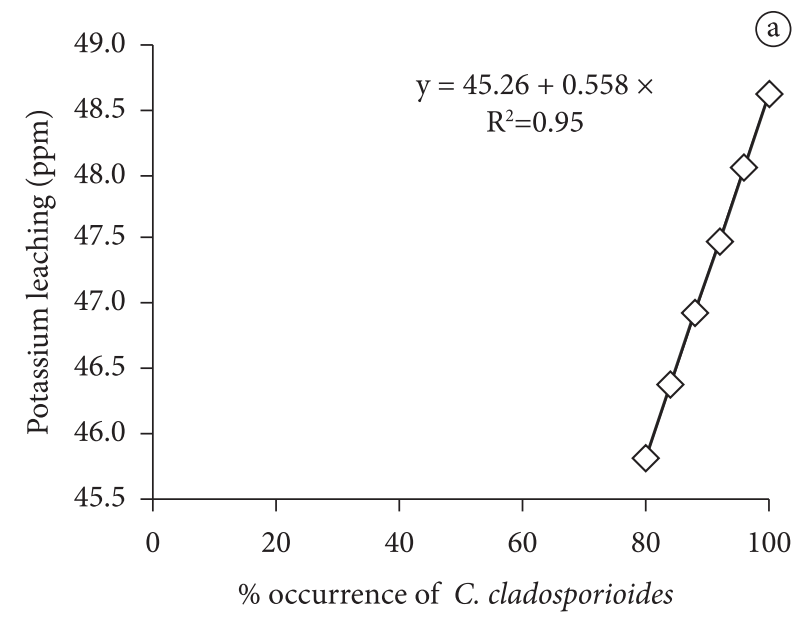

It was found that, in the presence of fungus, the amount of potassium leaching had a tendency to increase and that higher rates of leaching of this ion were found in samples of lower quality coffees, indicating that their membranes were affected. Previous studies demonstrated a positive relationship between potassium leaching and electrical conductivity, considering that the bulk electrical conductivity was found in grains that experienced greater potassium leaching (LOPES, 2000). Higher values for electrical conductivity confer a slight widening of the cell membrane and that, due to an increased susceptibility to injury, had a higher cytoplasmic translocation of ions to the liquid medium. Considering, also, the relationship of the state of organization of green beans membranes with the quality, the electrical conductivity of the exudate of the grains showed that the worse the quality of the drink, the greater the measure (PRETE; ABRAHÃO, 2000; SILVA et al., 2004). Among the factors that contribute to increase potassium leaching and electrical conductivity, it is the attack of microorganisms (LOPES, 2000). This study demonstrated the influence of Aspergillus alutaceus and C. cladosporioides fungi in electrical conductivity values (Figure 1c,d and 2a,b). However, other fungi detected in analyzed samples did not influence these parameters.

Figure 2. Effect of incidence (mean\% of occurrence) of the C cladosporioides fungus in potassium leaching (ppm) and electrical conductivity $(\mu / \mathrm{S} / \mathrm{g})$ in processed coffee beans.

Table 2. F values related to average levels of total sugars (\% DM), nonreducing sugars (\%), total acidity titled ( $\mathrm{mL} \mathrm{NaOH} 0.1 \mathrm{~N})$ and caffeine (\%) in samples of raw processed coffee.

\begin{tabular}{|c|c|c|c|c|}
\hline Sources of variation & Total sugars & Non-reducing sugar & Total acidity titled & Caffeine \\
\hline F. semitectum & $0.05^{\text {n.s }}$ & $0.09^{\text {n.s }}$ & $22.21^{\mathrm{n} . \mathrm{s}}$ & $0.05^{\mathrm{n} . \mathrm{s}}$ \\
\hline F. equiseti & $0.04^{\text {n.s }}$ & $0.82^{\text {n.s }}$ & $27.12^{\text {n.s }}$ & $0.42^{\text {n.s }}$ \\
\hline P. variable & $0.57^{\text {n.s }}$ & $0.32^{\text {n.s }}$ & $17.81^{\text {n.s }}$ & $0.33^{\text {n.s }}$ \\
\hline P. rugulosum & $0.10^{\mathrm{n} . \mathrm{s}}$ & $0.13^{\text {n.s }}$ & $19.98^{\text {n.s }}$ & $0.17^{\mathrm{n} . \mathrm{s}}$ \\
\hline P. funiculosum & $0.33^{\text {n.s }}$ & $0.42^{\text {n.s }}$ & $3.78^{\text {n.s }}$ & $0.41^{\mathrm{n} . s}$ \\
\hline Cladosporium & $0.32^{\text {n.s }}$ & $0.20^{\text {n.s }}$ & $0.32^{\text {n.s }}$ & $0.51^{\mathrm{n} . \mathrm{s}}$ \\
\hline Rhizopus & $0.04^{\mathrm{n} . \mathrm{s}}$ & $0.02^{\mathrm{n} . \mathrm{s}}$ & $0.03^{\text {n.s }}$ & $0.23^{\mathrm{n} . \mathrm{s}}$ \\
\hline Model & 4.2507 & 3.5656 & 1541.8647 & 0.01535 \\
\hline C.V(\%) & 8.76 & 8.96 & 3.62 & 5.40 \\
\hline
\end{tabular}

n.s. - not significant. 
The fungi associated with grains in the samples did not change the levels of caffeine, total acidity titles and sugars. It was observed that there was no significant effect $(p \leq 0.05)$ of fungi detected in the samples in any of these parameters (Table 2).

The acidity in various foods and beverages is a determinant factor in the formation and properties of the flavor. The level of acidity in coffee beans can vary with the levels of fermentation occurring in the grains and also with the different stages of maturation, which may serve as support to help evaluate the quality of coffee, since quality coffee index has lower acidity (COSTA; CHAGAS, 1997). In this study, it was shown that the fungi detected in the samples did not affect the total acidity of the grain.

Caffeine is one of the most studied chemicals, due to its physiological effects, mainly as a stimulant. The knowledge of caffeine levels interests mainly the markets that require low levels of these alkaloids, or even decaffeinated coffee. It was found that the fungi associated with grains in samples of raw coffee did not affect the levels of these constituents (Table 2).

Among the sugars present in coffee, no-reducing sugars stand out, particularly sucrose. There are low levels of reducing sugar. During the roasting process, the sugars react with amino acids to form colored compounds desirable for the color and aroma of the final product (COSTA; CHAGAS, 1997).

During the drying process, the mucilage is digested, providing food material for the seed and a continuation of their metabolism. These chemical changes alter the taste of coffee, which may be impaired or improved according to the presence or absence of micro-contaminants. The microorganisms produce enzymes that act on the chemical components of the mucilage, mainly on sugar, fermenting them and producing alcohol, which turns into acetic, lactic and butyric acids and others. The decrease in coffee quality begins when the production of propionic and butyric acids start (PIMENTA; VILELA, 2003). However, there was no change in sugar, depending on the occurrence of fungi detected in the analyzed samples (Table 2).

\section{Conclusions}

The results indicated that there is a trend towads the reduction of the PPO activity and the increase of potassium leaching and electrical conductivity amounts of the grains in the presence of Aspergillus alutaceus fungus. A trend towards the increase of electrical conductivity and potassium leaching values of the grains was detected in the presence of Cladosporium cladosporioides fungus. The fungi of the Fusarium and Penicillium genera, detected in the samples, did not interfere in any of the parameters. There was no change in total sugars - reducing and non-reducing, acidity, and caffeine in the presence of fungi detected in the samples.

\section{Acknowledgements}

The authors are grateful to the financial support provided by CBP \& D-Café; to CAPES, for the scholarship granted to L.A.A.P. Pasin, Federal University of Lavras; and to EPAMIG, for the opportunity to carry out this work.

\section{References}

ALVES, E.; CASTRO, H. A. Fungos associados ao café (Coffea arabica L.) nas fases pré e pós-colheita em lavouras da região de Lavras. Summa Phytopathologica, v. 24, n. 1, p. 04-07, 1998.

AMORIM, H. V. et al. Chemistry of Brazilian green coffee anal the quality of the beverage : II-Phenolic compounds. Turrialba, v. 24, n. 2, p. 217-221,1974.

ARAÚJO, J. M. Escurecimento enzimático em alimentos: Aspectos químicos e controle. Viçosa: UFV, 1990. 14 p. (Revisão, n. 231).

ASSOCIATION OF OFFICIAL ANALYTICAL CHEMIST - AOAC. Official methods of analysis of the Association of Official Analytical Chemists. 15th ed. Washigton: AOAC, 1990. 2 v.

BATISTA, L. R. et al. Toxigenic fungi associated with processed (green) coffee beans (Coffea arabica L.) International Journal of Food Microbiology, v. 85, n. 3, p. 293-300, 2003. http://dx.doi. org/10.1016/S0168-1605(02)00539-1

BATISTA, L. R.; CHALFOUN, S. M. Incidência de Ocratoxina A em diferentes frações do café (Coffea arabica L.) Bóia, mistura e varrição após secagem em terreiros de terra, asfalto e cimento. Ciência e Agrotecnologia, n. 31, p. 804-813, 2007.

CARVALHO, V. D. et al. Efeito do tipo de colheita e local de cultivo na composição físico-química e química do grão beneficiado. In: CONGRESSO BRASILEIRO DE PESQUISAS CAFEEIRAS, 15. 1989, Maringá. Resumos... Rio de Janeiro: MIC/IBC, 1989. p. 23-24.

CARVALHO, V. L. et al. Relação entre a composição físico-química e química do grão beneficiado e a qualidade da bebida do café. I. Atividade de polifenoloxidase peroroxidase, índice de coloração e acidez. Pesquisa Agropecuária Brasileira, v. 27, n. 3, p. 449-454. 1994.

CHALFOUN, S. M. O café (Coffea arabica L.) na região Sul de Minas Gerais - relação da qualidade com fatores ambientais, estruturais e tecnológicos. 1996. 154 f. Tese (Doutorado em Fitotecnia)Universidade Federal de Lavras, Lavras, 1996.

CHALFOUN, S. M.; BATISTA, L. R. Fungos associados a frutos de café Aspergillus \& Penicillium. Brasília: EMBRAPA, 2003.

COSTA, L.; CHAGAS, S. J. R. Gourmets - uma alternativa para o mercado de café. InformeAgropecuário, v. 18, n. 187, p. 63-67, 1997.

DRAETTA, I. S.; LIMA, D. C. Isolamentos e caracterização das polifenoloxidases do café. Coletânea do Instituto de Tecnologia de Alimentos, v. 7, p. 3-28, 1976.

FAVARIN, J. L. et al. Qualidade da bebida de café de frutos cereja submetidos a diferentes manejos pós-colheita. Pesquisa Agropecuária Brasileira, v. 39, n. 2, p. 187-192, 2004.

GARRUTI, R. S.; GONAGIN, A. Escala de valores para a avaliação da qualidade da bebida do café. Bragantia, v. 20, n. 18, p. 557-62, 1961. http://dx.doi.org/10.1590/S0006-87051961000100018

INSTITUTO ADOLFO LUTZ - IAL. Normas analíticas, métodos químicos e físicos para análise de alimentos. 3. ed. São Paulo: IAL, 1985. v. 1, p. 190-192.

KRYZYNOWSKI, F. C.; FRANÇANETO, J. B.; HENNING, A. A. Relatos dos testes de vigor disponíveis a grandes culturas. Informativo ABRATES, v. 1, n. 2, p. 15-50, 1991.

LOPES, L. M. V. Avaliação da qualidade dos grãos crus e torrados de cultivares de cafeeiros (Coffea arabica L.). 2000. 110 f. Dissertação (Mestrado em Ciências de Alimentos)-Universidade Federal de Lavras, Lavras, 2000. 
MENDONÇA, L. M. V. L. et al. Parâmetros bromatológicos de grãos crus e torrados de cultivares de café (Coffea arabica L). Ciência e Tecnologia de Alimentos, v. 25, n. 2, p. 239-243, 2005.

MENEZES, H. C. Variação dos monoisômeros e diisômeros do ácido cafeoilquímico com maturação de café. 1990. 171 f. Tese (Doutorado em Tecnologia de Alimentos)-Faculdade de engenharia de Alimentos, Universidade Estadual de Campinas, Campinas, 1990.

PONTING, J. D.; JOSLYNG, M. A. Ascorbic acid oxidation and browing in apple tissue extracts. Archives of Biochemistry, v. 19, p. 47-63, 1948.

PIMENTA, J. C.; VILELA, E. R. Composição microbiana e ocratoxina A no café (Coffea arabica L.) submetido a diferentes tempos de espera antes da secagem. Ciência e Agrotecnologia, v. 27, n. 6, p. 1315-1320, 2003.

PIMENTA, J. C.; VILLELA, T. C.; MORAES, A. L. L. Flora microbiana e qualidade do café (Coffea arabica L.) armazenado em coco por diferentes períodos. Revista Brasileira do Armazenamento, n. 5, p. 28-35, 2002.

POZZA, E. A. A. et al. A Qualidade do café e opções para o consumo. Belo Horizonte: EPAMIG, 2000.

PRETE, C. E. C.; ABRAHÃO, J. T. M. Condutividade elétrica do exsudato de grãos de diferentes cultivares de café (Coffea arabica L.). Semina: Ciências Agrárias, v. 21, n. 1, p. 67-70, 2000.

REINATO, C. H. R. Avaliação técnica, econômica e qualitativa do uso de lenha e GLP na secagem de café. Revista Brasileira de Armazenamento, n. 7, p. 3-13, 2003. Edição especial.

SILVA, C. F. et al. Microbial diversity during maturation and natural processing of coffee cherries of Coffea arabica in Brazil. International Journal of Food Microbiology, v. 60, p. 251-260, 2000. http://dx.doi.org/10.1016/S0168-1605(00)00315-9

SILVA, R. F. et al. Qualidade do café-cereja descacado produzido na região sul de Minas Gerais. Ciência e Agrotecnologia, v. 28, n. 6, p. 1367-1375, 2004. 